\title{
From the editor: Steering a policy turn in international business - opportunities and challenges
}

\author{
Ari Van Assche \\ HEC Montréal, Montreal, Canada; CIRANO, \\ Montreal, Canada \\ Correspondence: \\ A Van Assche, HEC Montréal, Montreal, \\ Canada. \\ Tel: +1(514)3406043; \\ Fax: +1(514)340-6987; \\ e-mail: ari.van-assche@hec.ca
}

\begin{abstract}
International business (IB) scholarship has developed a deep expertise in explaining how the international environment affects the behavior and strategies of firms, yet IB concepts continue to make limited inroads in policy circles. By comparing the fields of IB and international economics, I argue that a key reason behind this puzzle is that IB scholars have evolved into an epistemic community that builds on a frame of reference which is not adapted to policy practitioners' concerns. IB researchers have a strong focus on the performance of the firm from a private perspective, whereas policymakers are interested in the performance of countries or regions from a public or societal perspective. I discuss the steps that IB scholars need to take to translate their findings so that they become compatible with the societal viewpoint and therefore more readily useful to policymakers.

Journal of International Business Policy (2018) 1, 1 17-127.

https://doi.org/ | 0.1057/s422 I4-018-00 I3-0
\end{abstract}

Keywords: international business; policy; economics; frames of reference; translation problem

\section{INTRODUCTION}

International business (IB) as exemplified by the cross-border flows of trade and investment has been on the radar of policymakers for centuries (Rodrik, 1995). A large stream of research shows that trade and foreign direct investment (FDI) are important enablers of a country's economic growth, job creation and innovation capability, and these impacts unfold through various channels. IB allows countries to specialize their production activities, leading to a more efficient assignment of resources towards those sectors in which the country has a comparative advantage as well as towards those firms which are more productive (Melitz \& Redding, 2014). It exposes the constituent firms to foreign competition, which increases competitiveness and reduces prices (De Loecker \& Goldberg, 2014), and it allows local firms to tap into foreign knowledge that is unavailable locally, allowing for technological spillovers that stimulate local innovation (Turkina \& Van Assche, 2018). At the same time, IB comes at a cost. International trade and foreign investment have the potential to displace significant numbers of workers and 
generate negative externalities, creating large negative consequences for certain stakeholders in society (Autor, Dorn, \& Hanson, 2013). In this context, it is no surprise that governments around the world seek academic advice about the public policies they should adopt to optimally harness the benefits of trade and investment.

It is hardly a secret that policymakers have primarily turned to economists for their recommendations on IB policy. Research shows that the overall status of the economics discipline, the broad presence of economists in policymaking institutions, and the dominant role of economics in the cognitive infrastructure of policymaking have all helped bolster the ability of economics scholarship to influence policy discussions (Hirschman \& Berman, 2014). By contrast, the modest inroads of IB research into policy circles is a cause for concern (Buckley, Doh, \& Benischke, 2017). IB scholarship has in the past 50 years developed a strong expertise concerning the question how the international environment affects the activities, strategies, structures, and decision-making processes of different types of firms. These insights should arguably be the key building blocks in IB policy debates, since they directly tackle how changes in the economic landscape (including new policies) alter firm behavior. A recurring question among IB scholars is therefore what they can do to obtain a more prominent seat at the policy table (Lundan, 2018).

In this article, I aim to provide insights into this question by comparing the frames of reference that international economics (IE) and IB scholars adopt to analyze IB issues. My goal is to show that IB scholars have developed a strong focus on the performance of the firm from a private perspective, whereas IE researchers have concentrated on the performance of countries from a public or societal perspective. ${ }^{1}$ This difference in emphasis has allowed IB scholars to develop a powerful firm-centric lens with which to analyze how multinational enterprises (MNEs) organize themselves in a global context, but it has hindered them from pursuing the policy implications of their findings. I discuss what IB scholars need to do to translate their findings so that they become compatible with the societal viewpoint, and therefore more readily useful to policymakers. I finally provide an overview of the five papers included in this double issue that have successfully made a "policy turn".

\section{SOME EVIDENCE}

To get a rough measure of the influence of IB research on policy discussions, I have conducted a citation analysis of the leading economics and IB journals in four policy publications on international trade and investment policy: (1) a recent book that I have co-edited with Stephen Tapp and Robert Wolfe entitled Redesigning Canadian Trade Policy for New Global Realities (Tapp, Wolfe, \& Van Assche, 2017); (2) the World Trade Organization's annual publication World Trade Report over the period 2008-2017; (3) UNCTAD's annual publication World Investment Report over the period 20082017; and (4) the World Bank's new flagship publication Global Investment Competitiveness Report that was published for the first time in 2018. I have limited the citation analysis to six leading economics $^{2}$ journals and two leading IB journals: American Economic Review (AER), Quarterly Journal of Economics (QJE), Review of Economic Studies (RES), Journal of Political Economy (JPE), Econometrica (ECMA), Journal of International Economics (JIE), Journal of International Business Studies (JIBS) and Journal of World Business (JWB).

For the book Redesigning Canadian Trade Policy for New Global Realities, my co-editors and I invited 31 leading academics, government researchers, and practitioners to analyze how changes in global commerce, investment, technology, and geopolitical power are affecting Canada, and what this means for the country's trade and investment policy. Column 1 of Table 1 shows that in this book, all six economics journals were cited substantially more than JIBS and JWB. The two mostcited publications AER and JIE received 44 and 35 cites, respectively, whereas JIBS and JWB obtained nine and one cite. Furthermore, a closer analysis of the JIBS and JWB citations shows that they were entirely concentrated in two chapters that had been written by members of the Academy of International Business. Sui Sui cited JIBS six times and JWB one time in her chapter on SME trade (Sui \& Tapp, 2017), whereas I cited JIBS three times in my chapter on global value chains (Van Assche, 2017).

A citation count of leading economics and IB journals in the World Trade Organization's flagship publication World Trade Report over the period 2008-2017 provides a similar picture. In column 2 of Table 1 , the citation count of the six economics journals leads the pack, ranging from 240 for AER to 29 for ECMA. The number of citations of JIBS 
Table 1 Citation count of select economics and IB journals in leading IB policy publications

$\begin{array}{cccc}\text { Tapp et al. (2017) } & \begin{array}{c}\text { World Trade Report } \\ \text { 2008-2017 }\end{array} & \begin{array}{c}\text { World Investment } \\ \text { Report 2008-2017 }\end{array} & \begin{array}{c}\text { Global Investment } \\ \text { Competitiveness Report } \\ \text { 2017-2018 }\end{array} \\ (1) & (2) & (3) & (4) \\ 44 & 240 & 2 & 5 \\ 35 & 224 & 6 & 3 \\ 17 & 100 & 2 & 1 \\ 10 & 60 & 0 & 0 \\ 9 & 84 & 0 & 0 \\ 9 & 29 & 2 & 0 \\ 9 & 10 & 14 & 7 \\ 1 & 4 & 2 & 8\end{array}$

Journal of World Business

Source: author's calculations.

and JWB articles, in contrast, were significantly lower at 10 and 4 , respectively. Here again, the citations of IB articles were virtually all clustered in a single annual report: seven of the ten JIBS citations and three of the four JWB references were concentrated in the 2016 World Trade Report on "Levelling the Trading Field for SMEs".

The citation analysis of UNCTAD's flagship publication World Investment Report (2008-2017) and of the World Bank's newly released Global Investment Competitiveness Report provides a starkly different picture. In both publications, which focus on foreign direct investment, JIBS received substantially more citations than any of the economics journals. As is shown in column 3 of Table 1, JIBS received 14 citations in the various issues of the World Investment Report, which was more than the citations of all six economics journals combined. Column 4 of Table 1 shows that both JIBS and JWB received almost as many citations as the six economic journals combined.

These findings confirm the often heard concern among IB scholars that IB policy publications primarily rely on the field of IE to develop and support their policy views, but they also point out that there are select areas in which IB scholarship has carved out a dominant role, notably in the firmcentered areas of SME trade and FDI policy.

\section{FRAMES OF REFERENCE}

So why has extant IB research made few inroads into IB policy debates (with the exception of select areas)? Previous research suggests that there might be multiple factors at play. Policymakers and their staff, who are predominantly trained in economics, may be unaware of developments going on in IB, a discipline that is relatively self-contained and uses its own jargon and terminology (Beugelsdijk et al., 2013). They may also be uncomfortable with certain aspects of IB scholarship, and unfamiliar with some of the methodological approaches that are different from economics (Cuervo-Cazurra et al., 2016), and they may find that IB scholars have little to say about the grand challenges that policy practitioners want to address (Buckley et al., 2017). All these reasons undoubtedly hold some truth. However, I would like to suggest another perhaps more fundamental explanation that encompasses these previous concerns: IB research has over time evolved into an epistemic community that is distinct from IE, and that builds on a frame of reference which is not adapted to policy practitioners' societal concerns.

A key reason why policymakers have embraced the views of economists is that the latter are historically oriented towards improving performance from a societal perspective. In other words, the country-centric component of international business has been predominant in IE. International trade economists are interested in understanding why countries trade and how trade influences a country's aggregate welfare. In traditional trade models, this frame of reference has led to the development of various theories of the location of economic activity in which the place of value creation is entirely dependent on country-specific characteristics. Most notably, in the theory of comparative advantage, each country allocates its resources to the production and export of goods and services that require inputs in which it is well endowed, and imports those that require resources in which it is poorly endowed. It is precisely the ability of countries to voluntarily specialize in comparative 
advantage industries that makes a society (but not all types of workers) better off than under no trade. Using the same frame of reference, more recent trade models have introduced scale economies and product differentiation to their theoretical frameworks to explain trade between countries with similar endowments, but especially to uncover new mechanisms through which countries can gain from trade (Krugman, 1979, 1980).

At least until recently (I will come back to this later), international economists' focus on societal performance has inhibited them from paying much attention to the firm as an organizing unit (Dunning, 1995). To keep models tractable, traditional trade theories have treated firms as black boxes and have assumed away firm heterogeneity. Companies were assumed to be homogeneous, to focus on a single activity that is confined to their home country, and to operate in highly competitive conditions (perfectly or monopolistically). As a consequence, IE research has had relatively little to say about the wide variety of business strategies and structures that internationalizing firms adopt, and why this matters for policy.

IB scholarship has adopted a very different frame of reference to analyze the issues related to crossborder trade and investment. Focused on improving a firm's performance from a private perspective, IB researchers have primarily been interested in understanding why firms (and especially MNEs) conduct IB and how IB influences a firm's performance. In other words, IB researchers have primarily adopted a firm-centric view of international transactions. Opposite to IE, the existence of firm heterogeneity is axiomatic in IB. Firms possess or have access to firm-specific assets which their competitors do not have, and expanding operations internationally allows them to both nurture and exploit these firm-specific advantages. At the same time, firm internationalization comes at a three-pronged cost arising from organizational, market and institutional failures (Lundan, 2018). The most influential IB theories have gained their position by providing insights into how companies should optimally structure their activities, given the firm-specific advantages and costs that they face. To name just a few, internalization theory explains under which circumstances the MNE should exert proprietary control over their intangible knowledge-based assets abroad (Buckley \& Casson, 2009). The Uppsala internationalization model explains why it is often optimal for firms to gradually increase their commitment of resources when expanding into foreign markets (Vahlne \& Johansson, 2017). International new venture theory studies under which circumstances it is best for a newly established company to internationalize from inception (Oviatt \& McDougall, 1994).

The adoption of a private perspective in IB scholarship has created a powerful firm-centered lens with which to analyze how companies differentially organize themselves in a global context, and how this affects corporate performance, but it comes with the downside that IB theories are not necessarily adapted to policymakers' concerns. Policymakers might be interested in how firms conduct IB, but only if they understand why it is relevant from a societal viewpoint. As I will explain in greater detail below, a key challenge for IB scholars wishing to gain prominence in policy circles is how to translate their private-perspective findings in a way that is of importance from a societal point of view.

To summarize, the different frames of reference adopted by the fields of IB and IE explain to a large extent why trade policy has been the natural domain of IE, and business strategy the natural sphere of expertise of IB. IE scholars traditionally seek to understand performance differences between countries and focus on the policies that governments can adopt to improve aggregate competitiveness. In contrast, IB researchers generally strive to comprehend performance differences between companies and the strategies that managers can develop to strengthen firm performance. These differences emphasize the relative strengths and weaknesses of each field, yet they mask the research potential of combining insights from both fields for policy discussions. In the next section, we focus on two examples where scholars have successfully combined both private and societal perspectives to gain new policy-relevant insights.

\section{BRIDGING COMMUNITIES}

It is important to point out that some recent developments in both the fields of IE and IB have started blurring the distinction between the two epistemological communities, creating new opportunities for IB scholars to contribute to policy debates. First, firm heterogeneity has become a prominent topic in IE, which has transformed the field in a major way. Second, there has been a growing interest among IB scholars in examining how firms and locations co-evolve. In this section, I will provide a brief overview of these new 
developments and analyze what they imply for IB scholarship's potential to contribute to debates on public policy.

\section{Firm Heterogeneity in Economics}

Over the past few decades, international trade economists have started embracing the importance of firm heterogeneity for a country's aggregate trade and welfare. This recognition was initially instigated by the emergence of new micro-datasets which revealed that exporters are systematically larger, more skill- and capital-intensive, and pay higher wages than non-exporters within the same industry (Bernard et al., 2007). However, in line with economists' primary focus on how trade influences a country's welfare, this new focus only really started gaining traction when theoretical models showed that firm heterogeneity matters for understanding the gains from trade liberalization.

With more than 12,000 citations on Google Scholar, the most successful theoretical contribution in this vein is by Melitz (2003). The basic feature of the model is that a set of firms with different productivity levels face a similar fixed cost of exporting, but that only the most productive firms are profitable enough to overcome these fixed exporting costs. As a consequence, and in line with empirical evidence, only the "better" high-productivity firms self-select into becoming exporters, whereas less productive firms remain non-traders.

The appeal of the Melitz model is that it not only explains which firms trade and why, but it also identifies a new channel through which trade policy can enhance a country's welfare, namely by shifting the economy's resources from lowerproductivity firms to higher-productivity ones. When trade policy barriers fall, high-productivity exporters thrive and expand into foreign markets, while lower-productivity non-exporting firms shrink or exit in the face of heightened foreign competition. This reallocation of a country's economic resources from low-productivity firms to high-productivity firms increases aggregate productivity, an effect of trade policy that was largely neglected in previous theories of international trade; and the effect is not small. Balistreri, Hillberry, and Rutherford (2011) estimate that adding firm heterogeneity to standard computable equilibrium models of trade raises the gains from trade liberalization by a multiple of four.

The growing focus on firm heterogeneity by economists provides a welcome rapprochement between the disciplines of IE and IB. Once the importance of firm heterogeneity for societal performance had been established, economists have started searching for other firm features that might be relevant for societal welfare, at times building on IB insights. To name just a few, Bustos (2011) explored the link between firms' participation in international markets and their innovation activities at home. Whereas Melitz treated a firm's productivity as exogenously given, this study proposes that the increased profits accruing to productive firms after trade liberalization allow them to invest more in innovation at home, further boosting productivity. This new channel provides additional welfare gains from trade liberalization. Chor (2009) studied the welfare effects of subsidies to attract multinational corporations when firms are heterogeneous in their productivity levels. He shows that the use of a small subsidy raises welfare in the FDI host country, with the consumption gains from attracting more "high productivity" multinationals exceeding the direct cost of funding the subsidy program.

These recent developments in IE highlight two distinct ways how IB research can gain relevance in policy discussions. First, IB scholarship can provide firm-perspective foundations to IE scholars which they can use to develop their societal-perspective models on international trade and investment. Second, IB researchers can themselves redouble the efforts to theorize about how their privateperspective models translate into aggregate effects that are relevant for society at large. In the next section, I discuss an area where scholars have successfully made such a "policy turn" in IB research.

\section{Innovation-Driven MNEs and the Co-evolution of Firms and Locations}

There are select areas where IB scholars have deviated from their usual frame of reference by turning well-established private-perspective models into policy-relevant frameworks. One of the most notable examples is the work on the innovationdriven MNE, which has recently evolved into studying how firms and locations co-evolve (Cantwell, 2009; Cano-Kollmann et al., 2016).

Before getting into the model, let me point out that the theory of the innovation-driven MNE provides a nice example of the distinct views that IB and IE have on firms. While trade theory generally defines a firm without reference to other companies, IB researchers naturally characterize a 
firm on the basis of its exchanges with specific other actors. That is, IB scholarship acknowledges from the get-go that the MNE consists of a network of cross-border value-creating activities, some of which are carried out within the hierarchy of the firm and some which are carried out through informal social ties or contractual relationships (Cantwell et al., 2010).

What distinguishes the theory of the innovationdriven MNE from other IB theories is that it treats the inter-organizational network as a vehicle for MNEs to draw knowledge from different locations to strengthen their firm-specific capabilities (Cantwell, 1989). Specifically, MNEs deliberately establish cross-country linkages to actors in other locations in order to tap into pockets of complementary knowledge that are unavailable locally. Once new knowledge is accessed, they can use reverse knowledge transfer to enhance the parent firm's innovation through combinative knowledge generation. This approach has led to an influential literature in IB on the knowledge-seeking motive for IB networks (Berry, 2014; Chung \& Alcácer, 2002), on the existence of competence-creating subsidiaries and their role in enriching an MNE's network resources (Cantwell \& Mudambi, 2005), and on the importance of subsidiaries to be embedded in local business networks (Cantwell \& Mudambi, 2011).

While the early studies still took a private perspective by focusing on the importance of IB networks for the innovation performance of the MNE, several recent studies have considered the implications for the performance of locations. If many MNEs simultaneously attempt to strengthen their network resources by building linkages to firms or subsidiaries in a foreign location, this not only enhances the performance of the MNE itself, but it also fuels the development of the entire local innovation system. In other words, the very process of many firms accessing foreign knowledge through international business networks alters the characteristics of locations, setting in motion an intrinsic co-evolution of firms and locations (Cano-Kollmann et al., 2016; Cantwell et al., 2010). In a recent paper, Turkina and Van Assche (2018) indeed found that knowledge-intensive clusters which over time disproportionately improved their international connectedness to other knowledge hotspots through IB networks witnessed a larger increase in local innovation performance as compared to other clusters.
These IB-driven insights have provided policy circles with recommendations that are distinct from IE. They point out that locations need to develop smart international connectivity policies to strengthen the constituent firms' external network resources (see also the discussion of Iammarino's contribution in this issue). For example, new IB policies should aim to facilitate companies' ability to connect rapidly, safely and reliably with their IB partners so that domestic value-added activities can be better integrated into global knowledge networks (Van Assche, 2017). At the same time, depending on a location's relative position in the global knowledge network, policymakers should promote a different connectivity strategy to catalyze local innovation activities (Turkina \& Van Assche, 2018). Knowledge hotspots compete to attract and retain knowledge-intensive activities, and improvements in horizontal connectivity to other knowledge hotspots improves their chances to do so. In labor-intensive locations, then again, innovation catch-up depends on the ability to climb up the value chain, and improved vertical connectivity to more central value chain players is the best means to this end.

This example provides a powerful illustration of how IB scholarship has the potential to transform firm-centered ideas into policy-relevant frameworks. In her inaugural editorial, Lundan (2018) suggested that this applies to many more areas of IB research. She describes the field of IB a double helix structure, whereby some of the key theoretical concepts that IB scholars have used to understand MNEs from a private viewpoint have the potential of being equally relevant to public policy. As we will point out in the next section, however, effectively making this "policy turn" requires researchers to overcome a number of translation problems, so that the ideas become compatible with the societal perspective, and thereby recognizably useful to policymakers.

\section{TACKLING THE TRANSLATION PROBLEM}

Whereas IE has always been oriented towards informing policy, and the literature has been written from this frame of reference, IB scholarship does not have this tradition. As a consequence, IB researchers are required to make concerted efforts to translate their private-perspective concepts so that they become policy relevant. In this section, I will propose three actionable steps that researchers 
need to take to successfully conduct a policy turn in IB research.

\section{Focus on Policy-Relevant Concerns, Not Managerial Issues}

The first and most obvious recommendation is that IB scholars should identify research questions that are relevant for policymakers, and not only for managers. In practice, this implies that IB scholars should frame their papers in such a way that their private-perspective concepts gain pertinence for policy practitioners, and they should conduct empirical analyses that target new policy-relevant insights. Sometimes this requires an act of aggregation, in other words, asking what would be the consequences (desirable or undesirable) if multiple firms contemporaneously exhibited a certain behavior. At other times, it is simply a question of changing the perspective, and asking if the observed firm behavior is advantageous or disadvantageous from a societal point of view, and what policy tools could be employed to encourage or inhibit it.

It is important to point out here that developing policy-relevant ideas does not necessarily require IB scholars to completely overhaul or abandon their cherished models or empirical methods. In line with Lundan's (2018) double helix metaphor, the same theoretical concept or empirical finding in IB is often relevant for both managers and policymakers, but for different reasons. Consider a study on the impact of institutional voids (e.g., corruption) on inward FDI as an example. A manager may be interested in knowing how institutional voids or shortcomings affect a multinational firm's entry decision (e.g., Doh et al., 2017). A policymaker, then again, may be more concerned with how governments can manage or alleviate local institutional voids to attract foreign direct investment. The art of the "policy turn" is thus to identify how a similar framework can be relevant for different audiences.

\section{Embrace an Inter-Disciplinary Approach}

A second suggestion is that IB scholars should actively integrate theoretical and empirical developments from related disciplines to help motivate and develop the policy-relevance of their ideas. IB researchers have since long called for IB scholarship to take on a more interdisciplinary approach (Dunning, 1989; Cheng et al., 2009; Cantwell \& Brannen, 2011), yet I would argue that this recommendation is particularly relevant for the promotion of a "policy turn" in IB research. As we have seen with the example of firm heterogeneity in IE, frontier research in adjacent fields can be very useful for IB scholars to both legitimate the policy relevance of their work, and to identify new ways how their theories matter for societal performance. Mixing and matching interdisciplinary ideas from different areas can thus be a particularly powerful tool to make firm-centered concepts relevant for policy.

This is not to say that scholars should simply appropriate ideas from other disciplines. Rather, interdisciplinary research on IB policy requires a deliberate and considered use and integration of ideas and findings from different areas that provide novel insights into the cross-border flows of goods, services, capital, knowledge and people, and the aggregate implications for societies.

\section{Provide Clear, Nuanced, and Implementable Policy Recommendations}

The third recommendation is that IB scholars should pay special attention to the discussion of the policy implications of their analysis. In practice, this requires three things. First, researchers need to carefully describe what their analysis says and does not say about policy. Second, scholars need to discuss how the policy recommendations differ from received wisdom or established practices. Indeed, an IB-anchored paper that at the end of the day develops policy recommendations that are identical to conventional practices may have limited value in both academic and policy circles. Finally, researchers need to reflect on the extent to which policy recommendations are feasible or implementable by policymakers. Sometimes this requires a discussion what conditions need to be in place to operationalize policy suggestions. At other times, it involves a description what extra steps policymakers need to take (e.g., new data collection) to successfully put into practice a new policy. In any case, it requires a reasonable familiarity with existing policies and the decision-making context in which policymakers operate.

\section{PAPERS IN THIS ISSUE}

The second issue of the Journal of International Business Policy includes five original papers that have successfully conducted a "policy turn" by transforming private-perspective IB ideas into policy-relevant articles. The issue opens with three papers that (each in their own way) question the 
mindset of "inverse mercantilism" which to this day remains prevalent in many advanced economies' FDI policies. According to this mindset, it is in the interest of governments to attract foreignowned companies since inward FDI raises employment, exports and technology transfers. In contrast, there is low appeal for governments to help firms internationalize their operations since outward FDI may lead companies to substitute local employment and production for foreign workers and plants. All three papers build on concepts derived from IB theory to build their novel FDI policy insights.

In the first paper, Alvaro Cuervo-Cazurra analyzes the motives of Western governments to block inward FDI from state-owned enterprises (SOEs) originating from emerging markets, and discusses what it means for inward FDI policy. According to the author, the all-too-common government opposition against FDI from emerging-market SOEs is somewhat of a puzzle since the literature generally perceives inward FDI to bring net economic benefits to host economies. Cuervo-Cazurra argues that the source of the disproportionately negative sentiment against emerging-market SOEs can be dissected into the influence of state-ownership versus that of emerging market origin, and into the economic, political and psychological logics behind each of these effects. Policymakers primarily question the benefits of inward FDI from SOEs due to worries about these firms' non-business motives: SOEs might be driven by non-business objectives other than maximizing profits and long-term value, they face complex multilevel agency structures that heighten corporate opacity, and they may be used as soft power in their home country's foreign policy agenda. In contrast, policymakers' principal reservations about inward FDI from emerging-market firms concerns this type of firms' business motives: policymakers fear that the purchase of sophisticated technologies by emerging-market MNEs may hollow out a host country's strategic assets, they worry that emerging-market MNEs will transfer their sub-par governance practices to host-country firms, and they fear that the host country in the end will face a loss in its relative economic status. Taken together, these arguments provide a powerful IB-theory-grounded rationale why many Western governments hesitate to promote inward FDI from emerging-market SOEs.

Cuervo-Cazurra pays special care to discuss the implications of his analysis for inward FDI policy. He suggests that policymakers can abate many of the above-mentioned concerns with the development of a set of ex ante rule-based policies that exclude inward FDI in certain pre-defined national security sectors and that increase transparency in corporate governance through monitoring. This policy mixture can help mitigate the potentially negative consequences related to FDI from emerging-market SOEs, while at the same time limiting the ability of domestic interest groups to exploit the negative sentiments against emerging-market SOEs.

The next two papers, by Simona Iammarino and Peter Buckley, share two concerns about the received FDI policy wisdom. First, they both agree that, in today's age of global value chains, a rational FDI policy regime should not only focus on attracting IFDI, but also on promoting OFDI. As they point out, it has been widely established in the IB literature that firm internationalization can enhance efficiency, scale of operation and knowledge transfer, and that these firm-specific benefits may induce positive externalities in their home region which can catalyze sustainable growth and renew a location's competitive advantages. Any rational FDI policy regime thus requires a holistic strategy that integrates the silos of IFDI and OFDI. Second, both authors raise questions about the suitability of the nation-state as the archetypal unit of analysis for thinking about FDI policy, albeit in very different ways. Whereas Iammarino argues that it is essential to move the discourse of FDI policy to a more fine-grained sub-national level, Buckley emphasizes the need for stronger monitoring and policy setting at the supra-national level.

Iammarino builds her case for sub-national FDI policy on the growing empirical evidence that globalization and technological change have heightened territorial inequalities within countries. Core metropolitan areas have been the main beneficiaries of the transformation in the global division of labor, as complex economic activities and their associated political power have increasingly concentrated in these urban areas. In contrast, peripheral regions that specialize in routinized activities and occupations have been struggling to cope with globalization as they face tougher international competition from developing countries and receive lower nation-state protection.

Iammarino advocates that place-sensitive FDI policies, which are tailored to the specific connectivity needs of regions, can help mitigate the growing territorial polarization. Depending on a region's position in the core or periphery, its local 
economy benefits from the exposure to different types of assets and knowledge flows that originate from and are destined to other regions. A territorially differentiated FDI policy that allows regions to target their own desired connectivity can thus be a powerful tool to catalyze local economic development. The author presents the case studies of the three Celtic tiger economies - Southern \& Eastern Ireland, Scotland and Wales - to highlight the existing heterogeneity of place-specific FDI policies at the regional level and to discuss key principles that need to be taken into account for the development of a place-sensitive FDI policy.

In a conceptual contribution, Buckley develops a formal framework that is firmly based on extant international business theory to build the case for stronger monitoring and policy setting at the supranational level. According to the author, a key insight that derives from IB theory is that national policies influence the behavior and strategies of MNEs by affecting transaction costs, market imperfections or both. Buckley's contribution to this literature is the demonstration that a change in national policy affects transaction costs and market imperfections through four distinct channels: (1) by changing formal domestic institutions (e.g., identification and support of national security sectors), (2) by altering the way how governments and specific businesses interact (e.g., identification of national champions), (3) by modifying bilateral, plurilateral or multilateral relations with other countries (e.g., a bilateral investment treaty), and (4) by changing a country's socio-political and cultural networks (e.g., setting up targeted investment promotion agencies). This unpacking of national policy effects provides a workable framework to trace the various ways how policies affect transaction costs and market imperfections, and can thus help policymakers in the design of a rational FDI policy regime.

Buckley cautions, however, that policymakers should not only consider the national consequences of their policies, but also take into account the implications of their actions for other countries. It is well known that purely national policysetting such as low-tax policies may impose significant negative externalities upon other countries. These types of beggar-thy-neighbor policies can become welfare-deteriorating for the home country if other nations retaliate or enter a competitive bidding game. According to Buckley, his formal framework thus theoretically mandates supra-national monitoring to mitigate negative externalities spilling over from one national jurisdiction to another.

Aside from supra-national monitoring, Buckley argues that there is also a theoretically-motivated role for supra-national policy-setting which is commonly ignored by the extant literature. The conventional policy model for the implementation of "global goals" (e.g., Sustainable Development Goals) is that, even if these policy initiatives are agreed upon at the supranational level, they need to first be put into effect in national government policies before they can influence the behavior of MNEs. Buckley disagrees and argues that direct supra-national policy-setting which bypasses the national level can occur if an agreement on a nonbinding global policy goal is able to set in motion changes in the behavior and strategies of MNEs. He openly advocates for more IB research on how supra-national policy initiatives may influence MNE strategies.

The fourth paper, by Van Zanten and Van Tulder, provides an excellent response to Buckley's call for arms by studying the factors which influence a MNE's commitment to reach the Sustainable Development Goals (SDGs). According to the authors, governments not only impose policies to regulate MNEs' behaviors, but also work together with MNEs to shape institutions, which includes the development of policy agendas. A notable example of this public-private partnership in institution building is the United Nations' establishment of the Sustainable Development Goals (SDGs) in 2015. On the one hand, corporations were among the key stakeholders that were consulted for the formulation of the 17 Global Goals. On the other hand, active corporate engagement in moving towards the SDGs is repeatedly emphasized as a prerequisite for successful implementation of the SDGs. Building on institutional theory, Van Zanten and Van Tulder argue that the engagement of MNEs is influenced by both the specific SDGs and the characteristics of MNEs. First, MNEs are more likely to address sustainability challenges for which they can be held normatively accountable. This includes those actionable SDGs that firms can internally address within their own value chains (e.g., reduce corruption), and those ethical SDGs that focus on avoiding harm (e.g., minimize pollution). Second, MNEs which originate from certain countries and operate in particular industries are more likely to commit to sustainability actions than others. This includes MNEs from countries with precautionary principles (e.g., European countries) which are 
more likely to be held normatively accountable for addressing sustainable challenges than others. It also comprises MNEs that operate in industries which are associated with direct negative social and environmental impacts (e.g., mining). Using a survey of 81 FT Global 500 companies, the authors provide empirical findings in line with these predictions.

In the final paper, Murphree and Breznitz explore the types of technology standard policies that are able to promote technology upgrading in emerging countries. The authors point out that a vast literature has studied the determinants of a technology standard's adoption in the market and the welfare implications for consumers, but that little is known about the mechanisms through which technological standards affect a country's indigenous innovation capabilities. They consider this a lacuna in the literature since countries such as China have identified the development of technological standards as a key pillar in their national upgrading strategy. Using four cases of digital standardization in China, the authors find that two factors influence the impact of standard adoption on indigenous innovation: government support and standard openness. In the instances where the Chinese government provided broad state support for the development of the standard and constructed development standard policies that were open to both domestic and foreign firms (e.g., TDSCDMA), the cost of licensing a technology was significantly reduced and investments in $R \& D$ were considerably enhanced. In cases where the state commitment was restrained and/or standard developments were closed (e.g., EVD), the impact of standard adoption on both licensing fees and R\&D investment was limited. Thus the manner in which standard policies are implemented determines local innovation and economic outcomes.

\section{CONCLUSION}

The Academy of International Business has made a bold move by deciding to set up the Journal of International Business Policy (JIBP). There is tremendous potential for the discipline to enhance its relevance and broaden its impact by encouraging IB scholars to take a more prominent role in policy discussions at the sub-national, national, and supra-national level. However, successfully making a policy turn in IB research requires scholars to think outside of the box, and to adopt frames of reference that they perhaps currently are not yet used to. The editorial team of JIBP is fully aware of this translation challenge, and we are working diligently to support scholars who are willing to take the jump. One way we do this is through editorials. In her inaugural editorial, Lundan (2018) demonstrated that the same IB concept is often relevant for both managers and policymakers, albeit in different ways, something which she compared to a double helix. In this article, I have identified the source of the translation problem in the private versus public frame of reference, and have laid out a number of practical steps that IB scholars can take to make their findings more policy-relevant. Other ways we try to facilitate the policy turn is through the organization of panels and paper development workshops at prominent IB conferences. The panels allow us to showcase to aspiring researchers what high-quality IB policy research can look like; the paper development workshops allow us to provide one-to-one feedback to authors about what they should do to make their papers more policy-relevant. The final way we try to encourage scholars to take a leap is by publishing inspiring papers in JIBP. With the inclusion of five strong papers in this second double issue, I strongly believe we can call the birth year of JIBP a success.

\section{ACKNOWLEDGEMENTS}

I am grateful to JIBP Editor-in-Chief Sarianna Lundan, Ram Mudambi, and Jonathan Doh for their helpful comments on early drafts of this article.

\section{NOTES}

${ }^{1}$ Porter (1981) raised a similar question about the ability of industrial organization to contribute to the field of strategic management.

${ }^{2}$ The most influential economics articles on international trade and foreign investment are commonly published in the Big Five generalist journals AER, ECMA, $J P E, Q J E$ and $R E S$, as well as the field journal JIE. 


\section{REFERENCES}

Autor, D., Dorn, D., \& Hanson, G. 2013. The China syndrome: Local labor market effects of import competition in the United States. American Economic Review, 103(6): 2121-2168.

Balistreri, E. J., Hillberry, R. H., \& Rutherford, T. F. 2011. Structural estimation and solution of international trade models with heterogeneous firms. Journal of International Economics, 83(2): 95-108.

Bernard, A. B., Jensen, J. B., Redding, S. J., \& Schott, P. K. 2007. Firms in international trade. Journal of Economic Perspectives, 21(3): 105-130.

Berry, H. 2014. Global integration and innovation: Multicountry knowledge generation within MNCs. Strategic Management Journal, 35(6): 869-890.

Beugelsdijk, S., Brakman, S., van Ees, H., \& Garretsen, H. (Eds). 2013. Introduction. In Firms in the international economy: Firm heterogeneity meets international business. Cambridge, MA: MIT Press.

Buckley, P. J., \& Casson, M. C. 2009. The internalisation theory of the multinational enterprise: A review of the progress of a research agenda after 30 years. Journal of International Business Studies, 40(9): 1563-1580.

Buckley, P. J., Doh, J. P., \& Benischke, M. H. 2017. Towards a renaissance in international business research? Big questions, grand challenges, and the future of IB scholarship. Journal of International Business Studies, 48(9): 1045-1064.

Bustos, P. 2011. Trade liberalization, exports, and technology upgrading: Evidence on the impact of MERCOSUR on Argentinian firms. American Economic Review, 101(1): 304-340.

Cano-Kollmann, M., Cantwell, J., Hannigan, T. J., Mudambi, R., \& Song, J. 2016. Knowledge connectivity: An agenda for innovation research in international business. Journal of International Business Studies, 47(3): 255-262.

Cantwell, J. 1989. Technological innovation and multinational corporations. Oxford: Basil Blackwell.

Cantwell, J. 2009. Location and the multinational enterprise. Journal of International Business Studies, 40(1): 35-41.

Cantwell, J., \& Brannen, M. Y. 2011. Positioning JIBS as an interdisciplinary journal. Journal of International Business Studies, 42(1): 1-9.

Cantwell, J., Dunning, J. H., \& Lundan, S. M. 2010. An evolutionary approach to understanding international business activity: The co-evolution of MNEs and the institutional environment. Journal of International Business Studies, 41(4): 567-586.

Cantwell, I., \& Mudambi, R. 2005. MNE competence-creating subsidiary mandates. Strategic Management Journal, 26(12): 1109-1128.

Cantwell, J. A., \& Mudambi, R. 2011. Physical attraction and the geography of knowledge sourcing in multinational enterprises. Global Strategy Journal, 1(3-4): 206-232.

Cheng, J. L., Henisz, W. J., Roth, K., \& Swaminathan, A. 2009. From the Editors: Advancing interdisciplinary research in the field of international business: Prospects, issues and challenges. Journal of International Business Studies, 40(7): 10701074.

Chor, D. 2009. Subsidies for FDI: Implications from a model with heterogeneous firms. Journal of International Economics, 78(1): 113-125.

Chung, W., \& Alcácer, J. 2002. Knowledge seeking and location choice of foreign direct investment in the United States. Management Science, 48(12): 1534-1554.

De Loecker, J., \& Goldberg, P. 2014. Firm performance in a global market. Annual Review of Economics, 6(1): 201-227.
Doh, J., Rodrigues, S., Saka-Helmhout, A., \& Makhija, M. 2017. International business responses to institutional voids. Journal of International Business Studies, 48(3): 293-307.

Dunning, J. H. 1989. The study of international business: A plea for a more interdisciplinary approach. Journal of International Business Studies, 20(3): 411-436.

Dunning, J. H. 1995. What's wrong-and right-with trade theory? The International Trade Journal, 9(2): 163-202.

Hirschman, D., \& Berman, E. P. 2014. Do economists make policies? On the political effects of economics. Socio-Economic Review, 12(4): 779-811.

Krugman, P. R. 1979. Increasing returns, monopolistic competition, and international trade. Journal of International Economics, 9(4): 469-479.

Krugman, P. 1980. Scale economies, product differentiation, and the pattern of trade. The American Economic Review, 70(5): 950-959.

Lundan, S. 2018. From the editor: Engaging international business scholars with public policy issues. Journal of International Business Policy, 1(1): 1-11.

Melitz, M. I. 2003. The impact of trade on intra-industry reallocations and aggregate industry productivity. Econometrica, 71(6): 1695-1725.

Melitz, M., \& Redding, S. 2014. Heterogeneous firms and trade. In Handbook of international economics, Vol. 4: 1-54. Elsevier.

Oviatt, B. M., \& McDougall, P. P. 1994. Toward a theory of international new ventures. Journal of International Business Studies, 25(1): 45-64.

Porter, M. E. 1981. The contributions of industrial organization to strategic management. Academy of Management Review, 6(4): 609-620.

Rodrik, D. 1995. Political economy of trade policy. Handbook of International Economics, 3: 1457-1494.

Sui, S., \& Tapp, S. 2017. Going global: Canadian SME trade and emerging markets. In S. Tapp, A. Van Assche, \& R. Wolfe (Eds), Redesigning Canadian trade policies for new global realities. Montréal: McGill Queen's University Press.

Tapp, S., Van Assche, A., \& Wolfe, R. 2017. Redesigning Canadian trade policies for new global realities. Montréal: McGill Queen's University Press.

Turkina, E., \& Van Assche, A. 2018. Global connectedness and local innovation in industrial clusters. Journal of International Business Studies, 49(6): 706-728.

Vahlne, J. E., \& Johansson, J. 2017. The internationalization process 1977-2017: The Uppsala Model 40 years later. Journal of International Business Studies.

Van Assche, A. 2017. Global value chains and the rise of a supply chain mindset. In S. Tapp, A. Van Assche \& R. Wolfe (Eds), Redesigning Canadian trade policies for new global realities: 183-208. Montréal: McGill Queen's University Press.

\section{ABOUT THE AUTHOR}

Ari Van Assche is Associate Professor of International Business at HEC Montréal and deputy editor of the Journal of International Business Policy. His research focuses on the organization of global value chains and their implications for international trade and industrial clusters. 